\title{
Preface to the Twentieth Anniversary Edition
}

A veritable spate of works on the Mongols has appeared in the two decades or so since this book was originally published. One popularization, based on a doubtful and distorted use of scholarly studies, even reached the best-seller lists and influenced serious books on current foreign policy. Another proclaimed, strangely enough, that Khubilai Khan's grandfather Chinggis Khan adopted democratic principles in ruling his domain. A movie reputedly recounting Chinggis's life was one of the five contenders for the 2007 Academy Award for Best Foreign Language Film. Naturally, reliable, informed, and informative studies on the Mongols have also been published and have offered a more detailed and accurate view of the largest contiguous empire in world history. This book on Khubilai has profited from such increased interest in the Mongols. French and Italian translations appeared within two years of its publication, but in the past year the pace has accelerated. Russian, Chinese, and Korean translations have suddenly been published.

Part of this interest in the Mongols derives from a greater appreciation of global history. Historians have founded a World History Association, with its own Journal of World History. Colleges and secondary schools have begun to require courses on the non-Western civilizations, especially focusing on links between East and West. The Mongols are critical in this growing trend toward interlocking histories because their era witnessed the first direct relations between Europe and China. Marco Polo symbolizes this contact, but missionaries, Genoese 
and Venetian merchants, and a French silversmith-not to mention Iranian, Central Asian, and Armenian astronomers, soldiers, officials, traders, weavers, and rulers-also reached East Asia. Mongol expansion into Eastern Europe and West Asia and the ensuing contacts with the West mark the inception of global history.

Mongolia's reengagement with the world starting in 1990 also contributed to renewed interest in the Mongols' thirteenth- and fourteenthcentury empire. From 1921 to 1990 , socialist Mongolia dealt principally with the USSR and Eastern Europe, but the collapse of the Soviet Union and Mongolia's opening to East Asia and the West permitted many foreigners to enter the country and prompted considerable attention to the Mongols' history. In Mongolia, archeological research, studies of contemporary pastoral nomadism as a guide in understanding the traditional economy, and analyses of climate in the twelfth and thirteenth centuries have all offered insights into the background of the Mongol Empire. Such studies in Mongolia have stimulated both scholars and popularizers to produce books and articles on the Mongol era.

These works have, in particular, added to knowledge of the Mongol domains in West Asia and Russia. A number of studies on the Iranian artistic and cultural renaissance have appeared, culminating in a much-lauded museum exhibition on Chinese influence on Iranian art. Books on the tripartite conflicts among the Mamluks of Egypt, the Golden Horde in Russia, and the Il-Khan rulers of the Middle East have revealed the rifts within the various Mongol khanates, which undermined the empire and eventually led to its collapse. The Golden Horde and the Mongol impact have also attracted attention. In addition, prompted by the fascination with Marco Polo, global history has come to the fore, as several books have illuminated relations between Europeans and the Mongols.

Several studies of Mongol rule in China have also been published. The Cambridge History of China: Alien Regimes and Border States, 907-1368, the most important such publication, offers a summary of the political and economic developments in each Mongol-established Yuan dynasty reign. A recent edited volume on the so-called Song-Yuan-Ming transition focuses on the Song and Ming dynasties, but it presents a few insights on the Mongol era as well. Books or essays on Mongol governmental institutions in China and developments in medicine and in women's property rights have also appeared. Although many aspects of Yuan dynasty rule have not been adequately studied, these 
preliminary works have provided valuable glimpses of developments during that time. Studies of Yuan foreign relations, especially during Khubilai's reign, have resulted in greater understanding of the Mongol invasions of Japan and Java, as well as of the Yuan dynasty's commercial relations with India and West Asia. These studies have supplemented the portraits depicted in this book. Indeed, they have prompted me somewhat to modify some specific assertions.

I have concluded, for example, that the Chinese sources inflated the figures of the military forces in the abortive 1281 invasion of Japan. The Chinese accounts cite the number 140,000 as the size of the invading army, which would make it an extremely large expedition for that era. Thomas Conlan, using Japanese sources, has suggested that the expedition consisted of far fewer troops. Nonetheless, the expenditures lavished on the mission confirm that the fighting force was sizable. In fact, revenue shortfalls, precipitated in part by these costs, bedeviled Yuan China from the time of the Japanese invasions. Thus I doubt that the number of troops was as small as 10,000 , a figure that critics of the Yuan histories cite. Suffice it to say that the figure of 140,000 is an exaggeration, but half of that may not be off the mark.

Perhaps more critical than such details are the somewhat differing emphases I might have incorporated in the book if I were writing it today. When it appeared, many educated readers, in both East and West, perceived the Mongols as plundering, rapacious, and murderous and believed that their invasions and rule were destructive, if not disastrous. This book and a few others written during that time challenged this totally negative depiction of the Mongols and of their influence on the countries they governed. These works focused on the Mongols' contributions to trade, relations between East and West, and cultural, religious, artistic, and technological diffusion-indeed to globalization, to use the currently fashionable term. This book also described Khubilai's generally benevolent attitude toward foreign religions and his recruitment of a multiethnic coterie of officials to assist in ruling China, a refutation of the conventional wisdom concerning the Mongols' objectives of massacring and razing rather than rebuilding and ruling.

In the past two decades, however, popular writers, using this and other books, started to portray the Mongols in heroic terms, approaching a hagiography of Mongol leaders such as Chinggis Khan and Khubilai. They depicted Chinggis Khan as the harbinger of the modern world in his attitudes and policies and as a symbol of democracy 
because of his alleged consultation with the nobility on important decisions and his support of women's rights. Emphasizing the Pax Mongolica, the general peace that prevailed over much of Asia during the Mongol era, they tended to ignore the darker and more brutal side of the Mongol invasions. This distorted image of the Mongol Empire, unfortunately, appears to be gaining greater popular acceptance.

Although I attempted to present a balanced portrait of Khubilai and his reign, I probably should have devoted more attention to the destruction he unleashed. Hundreds of thousands and perhaps millions were killed during his military campaigns in South China, Korea, Southeast Asia, Japan, Central Asia, and Manchuria, and his troops devastated many regions, both cities and rural areas. The violence in these expeditions was unremitting. To ignore the bloodshed and the colossal damage would be ahistorical and would present an inaccurate view of Khubilai's and the Mongols' impact on East and Southeast Asia. Khubilai's contributions to governance and stability, religious toleration, reassessment of occupations and professions, and Chinese art and theater should not be overlooked, but neither should the conquests and ensuing horrors be whitewashed.

A more positive note about Khubilai and his reign, which I alluded to but did not fully explore, was his support for Chinese art and the resulting artistic diffusion to other parts of the Mongol Empire. Tangible objects naturally offer easier means of observing and identifying diffusion between cultures, and West Asian art of the Mongol era reveals the palpable influence of Chinese art. Because Khubilai maintained good relations with the Il-Khanate of Iran, the Mongol-ruled domain established by his brother and his nephews, there was considerable interchange between China and West Asia. After the publication of this book, When Silk Was Gold (an exhibition at the Cleveland Museum of Art and the Metropolitan Museum of Art in 1997-98) and The Legacy of Genghis Khan: Courtly Art and Culture in Western Asia, 1256-1353 (an exhibition at the Metropolitan Museum of Art and the Los Angeles Museum of Art in 2002-3) attested to the Iranian borrowing from China. Iranian potters sought to imitate Chinese celadons and incorporated Chinese designs on their wares. Similarly, quintessential Chinese designs, such as the dragon and the phoenix, and imitations of trees and clouds in Chinese landscape paintings appeared in the Iranian illustrated manuscripts of this era, including the renowned Rashid al-Din's world history. Khubilai should be given credit for fostering such artistic interchanges. 
As additional research and more publications appear and as I continue to study and to experience more, the depiction of Khubilai and his times in this book may require reassessment. I think, however, that such changes will not, in the near future, alter the portrait I have drawn in the book, and I trust that scholars and general readers will find this biography accessible.

This book was in manuscript and then in print before the pinyin system of transliterating Chinese became pervasive. The expense of converting from the Wade-Giles system to pinyin would have led to a price increase for this reissue of the book. Thus I have not changed to pinyin, in the belief that the reader can readily find conversion tables for the two systems. I wish to acknowledge the assistance of Sarah and Nathan Sterinbach while I was writing this preface.

New York City April 2009 
This page intentionally left blank 